\title{
THE ECOLOGY OF BRITISH UPLAND LANDSCAPES. II. THE INFLUENCE OF POLICY ON THE CURRENT CHARACTER OF THE UPLANDS AND THE POTENTIAL FOR CHANGE
}

\author{
ROBERT G.H. BUNCE ${ }^{1}$, ClAIRE M. WOOD ${ }^{2 *}$, SIMON M. SMART ${ }^{2}$ \\ ${ }^{1}$ Estonian University of Life Sciences, Kreuzwaldi 5, 51014 Tartu, Estonia. \\ ${ }^{2}$ Centre for Ecology \& Hydrology, Lancaster Environment Centre, Library Avenue, \\ Bailrigg, Lancaster, LA1 4AP, UK \\ *Corresponding authore-mail: clamw@ceh.ac.uk
}

Received: $30^{\text {th }}$ October 2018, Accepted: $21^{\text {th }}$ December 2018

\begin{abstract}
The paper demonstrates that the British Uplands have been influenced to a great extent by policy - for example, the planting of almost a million hectares of exotic conifers since the Second World War, and the extent of designated areas. Otherwise, climate change transcends policy and is locally important to coastal and high mountain habitats. The different policies affecting the Uplands, such as the Common Agricultural Policy, are described, as are the wide range of designations such as National Parks, which may have a stabilising effect in times of great change. A new trend has started in Scotland in the last 20 years of local initiatives, such as the community ownership of Eigg, however large landowners still dominate. An impact table is presented of the habitats that make up the Uplands and their links to driving forces, with potential changes described that are likely to take place under future policies such as Brexit. Dwarf shrub heath is the habitat affected by many management drivers, whereas habitats such as Inland Rock, are relatively stable but most likely to be affected by climate change.
\end{abstract}

Keywords: Brexit, Designated areas, Common Agricultural Policy, Forestry policy, privatisation, impact table, UK Biodiversity Action Plan, Habitats, re-wilding

\section{INTRODUCTION}

Policy has been a major determinant in the composition and character of the British Uplands, especially in influencing agricultural and forestry land uses, but also in initiatives such as the Wildlife and Countryside Bill of 1981. The current situation is complex and confused, especially in relation to Brexit which could change the whole structure of agriculture in the Uplands. The government pronouncements are full of contradictions, with on the one hand the view that agricultural subsidies should be linked to environmentally friendly management, but alternatively only profitable agriculture should continue. Such a policy would lead to abandonment in the uplands as discussed by Benayas et al. (2007).

A comprehensive review of the current situation is provided by Evans et al. (2017), who concluded that policies were required to build resilient and restorable ecosystems, with renewable energy, woodland expansion and the issues of the burning of heather moors featuring strongly in the discussions. It was agreed that ecologists need to develop integrated 
policy options and management strategies for the Uplands following the policy statements of the Scottish Government (2016) and Scottish Natural Heritage (2016).

The present paper firstly reviews the range of policy initiatives which have taken place since the Second World War, both in terms of Government, as well as Non-Governmental Organisations. In the final section, an Impacts Table approach is used, as described by Petit et al. (2001) which summarises the principal drivers affecting habitats in the Uplands and indicates the links between them and potential changes and policies. The difference in the present paper from Petit et al. (2001), is that integrated estimates of the area of habitats in England, Wales and Scotland are presented, derived from Paper I (Bunce et al., 2018). Expert judgement therefore only concerns the link between the drivers and the habitats. It should be emphasised that only key references are given in the present paper because otherwise it would become too long and unreadable, but Firbank et al. (2000) contain more detailed relevant information.

\section{MATERIALS AND METHODS}

A full description of the method used to derive the figures for the extent of habitats in the Uplands is given in the first paper (Bunce et al., 2018). In summary, these were statistically estimated from stratified random field samples, based on statistically derived Environmental Classes (Bunce et al., 1996). The categories used are those described in the UK Biodiversity Action Plan JNCC (Jackson, 2000), in order to ensure familiarity with British readers, and to ensure that they are linked directly to the policies of the main conservation agencies. They are also used for presenting the results of the Countryside Survey, as given in Carey et al. (2008) and Norton et al. (2012). The Broad Habitats used are those that are restricted to the upland landscapes described in the first paper (Bunce et al., 2018), thus habitats such as lowland heathland and raised bogs are not covered.

The impacts table approach was developed by Petit et al. (2001) in order to formalise the links between expert opinion on the drivers that are affecting particular habitats and their impacts on them. In that paper, the Driving Forces Impacts and Response (DPSIR) framework was used, but in the present paper only the state is described and the links are then made to policies or other impacts such as climate change. For example, silage making only affects intensively managed agricultural grasslands, not arable crops. A definitive link can therefore be made between the driver and the particular habitat, in this case fertile grasslands. This method is therefore useful in presenting an integrated picture of the current pressures on habitats and has also been used by Petit \& Elbersen (2006) for calcareous grasslands as a comparable approach. Firbank et al. (2000) used a similar approach to identify the causes of change in British vegetation. Petit et al. (2001) included acidification which is not now so high on the policy agenda, but otherwise all the drivers included in this paper were covered in this paper and expanded where necessary.

\section{LAND USE IN THE UPLANDS}

\section{Forestry}

Since the Second World War, there has been a series of government policies mainly designed to develop a strategic reserve of timber. These have involved financial support to the state owned Forestry Commission but also for tax incentives to private companies and individuals, as described by Aldhous (1997). 
Bunce R.G.H., Wood C.M., Smart S.M.: The Ecology of British Upland Landscapes. II. The influence of policy on the current character of the Uplands and the potential for change

In both cases, the majority of plantations, usually of exotic conifer species, especially Picea sitchensis (Sitka spruce) and Pinus contorta (lodgepole pine), would not otherwise be financially viable. The figures presented in Bunce et al. (2014) show that these plantations have increased by almost $300 \%$ since 1947. Bunce et al. (2014) describe how these exotic plantations have completely altered the character of many upland landscapes, as well as their landscape ecology. There is also a modern trend not to carry out thinning, but to clear fell large areas because of efficiencies of scale. Currently the most recent trend is privatisation of forests, for example, in Dumfries and Galloway, but there is no indication of the likely future trend in this process.

\section{Agriculture}

Agriculture has also been supported by government subsidies in an analogous way to forestry, partly to maintain the tradition of hill farming, but also to produce food and conserve the landscape character of grazed hills. Fennell (1997) and Ackrill (2000) describe the process by which the Common Agriculture Policy became the procedure for determining the means of subsidy and its extent - culminating in the Single Farm Payment system which has led to many problems. Knudsen (2009) also summarises how farmers depend on subsidies and agri-environment schemes. Sheep have always been in high numbers in the Uplands but numbers increased greatly after entry to the EU, with figures being provided by Silcock et al. (2012) and their implications for biodiversity.

\section{Renewable energy}

The current potential for renewables are summarised by Lund \& Münster (2006) and Jacobsen \& Delucchi (2011) but the costs are changing rapidly, for example, in the case of the decreasing costs of electricity generation in off-shore wind farms (Harrabin, 2017). In the past, hydro-power schemes have had a major impact locally but these are not currently a major issue. The current major pressure is from wind farms and associated power lines. These are controversial mainly from their scenic impact, although their environmental effects are open to discussion, as described by Saidur et al. (2011). There are differences between the English and the devolved Welsh and Scottish governments about renewable energy policies, and the situation is by no means clear.

\section{Re-wilding}

This is a term that is now widely used to describe the process of returning landscapes to a more natural balance, but is often used indiscriminately in relation to the removal of sheep from the Uplands. The term was first used in the literature by Soule \& Noss (1998) and in more detail by Monbiot (2013) and recently Pettorelli et al. (2018). There is now an organisation "Re-wilding Britain" (https://www.rewildingbritain.org.uk/) whose objective is to mainstream re-wilding, and whose mission is to demonstrate that re-wilding works by carrying out pilot projects. This process is often assumed to be beneficial and lead to a return to forest, but there are major gaps in the provision of policy advice. However, the impact of such removal will vary widely between soil type, altitude, the structure of the landscape and the existing character of the vegetation. Tree regeneration can be rapid and successful.

In this context, the introduction of species is often discussed. Whilst some of these have been successful (such as the white tailed eagle), others currently in progress, such as the beaver, are more controversial, and the wolf even more so. 


\section{Game management}

The whole topic of game management is so controversial that it is not the intention in this paper to follow the many issues involved. However, no discussion of land use in the Uplands would be complete without mentioning the role of game in the region (for example, about $0.75 \mathrm{~m}$ ha are used by grouse and $1.5 \mathrm{~m}$ ha by deer (Bunce et al., 2018)). For many estates, the primary objectives relate to deer and grouse management and this affects the structure and composition of the vegetation to a major degree. The reader is therefore referred to the following publications to read descriptions of the practices involved. For deer, Griffith (2011) and Potter (2014) and for grouse, British Association for Shooting and Conservation (BASC) (2017), Davies et al. (2016); Malcolm \& Maxwell (2018); Sandercock \& Martin (2011) and Grant et al. (2012).

\section{Leisure and Tourism}

The main direct use of land for these activities is mainly around ski centres, chair lifts and water sport centres. There are also pressures from walkers and climbers on footpaths and cliffs. The other influences are in the development of urban areas for accommodation and tourist activities, which have been increasing in towns such as Fort William and Inverness and many villages in South West England and Wales. However, as with the previous topic, it is only the purpose of this paper to indicate that this is an important, strong pressure that has a large and complex literature which is beyond the scope of the present paper to summarise.

\section{Designations}

The following designations are present in the Uplands:

\section{- National Parks}

Most of British parks are in the Uplands, and the majority are in England and Wales, reflecting the importance of the landscape character of upland landscapes and their value to the public. Each Park has its own planning guidelines, and until recently these have been very effective in restricting damaging developments. However, there is now recent pressure from the government to relax these constrictions, such as allowing zip-wires in the Lake District (Quinn, 2018).

\section{- National Nature Reserves}

These have stricter controls than National Parks, and many of the sites in the Natura 2000 series of the EU are designed to protect threatened and important habitats such as woodlands and calcareous grasslands.

\section{- $\quad$ Sites of Special Scientific interest}

These are designated for the same reasons as the previous category, but are not so strongly protected and can be destroyed by government developments.

\section{- Areas of Outstanding Natural Beauty and Scenic Areas in Scotland}

These recognise the landscape significance of certain area but with lesser controls than those described above.

Whilst large areas of the British uplands are protected, it is often difficult to assess the effectiveness of this protection. Although studies can demonstrate the relatively 'high' quality of protected sites, it is difficult to say whether this is due to the effectiveness of the designation, or whether the designation was made because of the quality of the area in the first place (for example, see Barr (1996). There are still gaps in the protected area network, the conservation status of many protected areas remains in doubt, and the whole system of protection could change dramatically post-Brexit. For example, the Environment Land Management system proposed by the UK government (DEFRA, 2018), would switch from a 
Bunce R.G.H., Wood C.M., Smart S.M.: The Ecology of British Upland Landscapes. II. The influence of policy on the current character of the Uplands and the potential for change

system of subsidy (single farm payments) to payments for public benefits of ecosystem services provided by landowners. This would radically change the social and economic character of upland farming with potentially significant impacts on ecology.

\section{Non-Governmental Organisations involved in management}

The National Trust now owns extensive areas of the Uplands, for example the Mar Lodge Estate in Scotland and Great Gable in the Lake District, and are instrumental in ensuring their maintenance. The John Muir Trust also owns much of Knoydart in the west of Scotland, as well as the summit of Ben Nevis, and also advises on management of Helvellyn in the English Lake District. The Trust also opposes developments that threaten wilderness areas, for example wind farms.

The Crofting Commission also supports crofting in order to maintain the traditional small scale farming involved.

Other individual initiatives (for example, the Carrifran new forest in the Borders), and Trusts (such as The Sir John Knott Trust in College Valley in the Cheviots), may also carry out policies which do not fit the overall pattern. Finally, community ownership, as on the island of Eigg, has also been successful in breaking away from the dominance of large landowners.

In summary therefore, there are many levels of protection in the Uplands, which could well reduce the effect of abandonment which might follow Brexit (for example the National Trust may well continue to subsidise farming to continue in the Lake District).

The impact table of Figure 1 uses the Broad Habitats of the UK Biodiversity Action Plan (Jackson, 2000) as a framework together with the associated drivers linked to possible policy changes, following the procedure described by Petit et al. (2001). The Broad Habitats form the rows and the columns define the drivers 


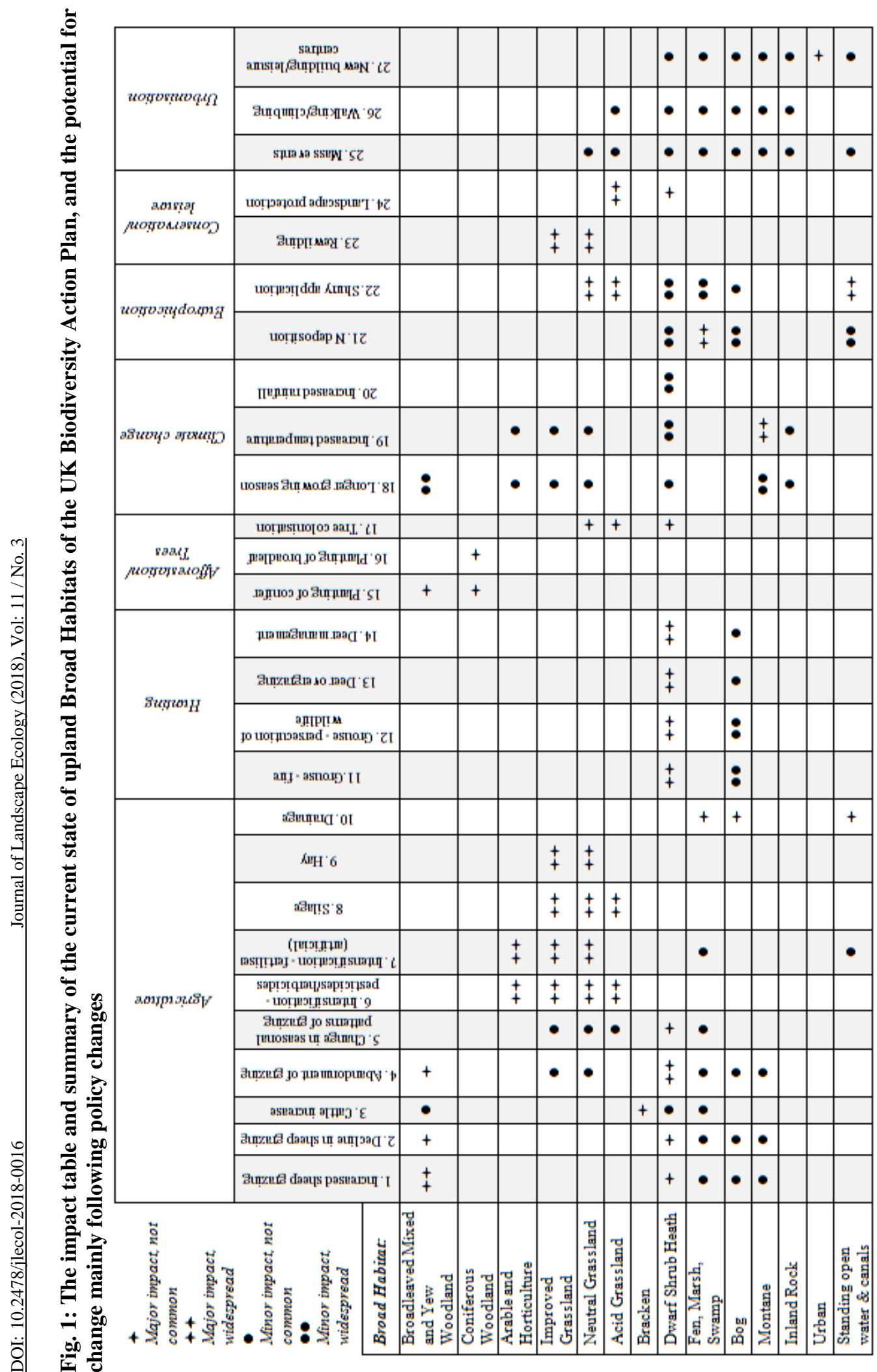




\section{Interpretation of the Impacts Table and links to past and potential future policy}

The figures given are percentages taken from Tables 2 or 4 in Part I of this paper (Bunce et al., 2018). NA= Habitat too restricted to obtain significant estimates. The $\%$ figures from the previous paper are given so that the extent of the habitats can be seen. E = England, $\mathrm{S}=$ Scotland and $\mathrm{W}=$ Wales.

\section{Deciduous Forest (E: $3 \%$, S: $2 \%$, W: $9 \%$ )}

State: woods are important in both landscape and biodiversity terms. Currently, most are intensively grazed with a highly modified ground flora and usually no regeneration.

Potential changes: reduction in sheep grazing following Brexit would have an immediate positive effect. Deer are unlikely to be so affected and could even increase with less competition for grazing.

\section{Coniferous Forest (E: $5 \%$, S: $14 \%$, W: $10 \%$ )}

State. The majority are dense plantations with virtually no ground vegetation, mainly Sitka spruce (Picea sitchensis). Some landscapes are completely dominated by such stands and have changed the hydrology (Robinson, 1986) as well as the entire structure of the valleys involved, as discussed in Bunce et al. (2014). Native Pinewoods are an exception and are protected.

Potential changes: the price of timber and pulp could rapidly change the rate of felling. As prices are increasing at present (Forest Research, 2018), more felling could result. Policy support for new and replacement plantations could have a major impact and cause reductions in acid grassland and bog habitats. The situation is therefore in flux, and future directions are not possible to predict except to comment that very large areas are likely to be involved. The increased clear felling of large plantations has major environmental impacts such as nitrogen flux and sedimentation in rivers and lakes (Reynolds \& Edwards, 1995).

\section{Arable (E: $2 \%$, S: NA, W: NA)}

State: although restricted in extent, this habitat is important to landscape heterogeneity and biodiversity - especially for feeding birds such as geese, for example greylag (Anser anser). Originally in the crofting communities of the north and west of Scotland, the small patches of arable land had a diverse weed flora (Angus, 2009).

Potential changes: A change in support for crofters and agri-environmental schemes would have an immediate effect and enhance the existing shift to grassland or to abandonment in extreme scenarios.

Improved Grassland (E: $15 \%$, S: $6 \%$, W: $26 \%$ )

State: The figures show the surprising extent of fertile grass in the uplands, which is mainly due to the widespread occurrence of glacial valleys. This habitat also contributes to landscape diversity and biodiversity, and is an important feeding ground for moorland birds. Currently many such fields are subjected to intense fertiliser use and slurry application. A detailed discussion of the impact of eutrophication is given in Petit et al. (2001). Modern silage cutting has also had effects on ground nesting birds (Vickery et al., 2001).

Potential changes: this will be the last of the land to be abandoned, and it is possible that the removal of subsidies could lead to the destruction of boundaries and the creation of large fields and big farms occupying only the better land (see also the next category). Designations such as National Parks and owners such as the National Trust could have a mediating effect. 
Neutral Grassland (E: $16 \%$, S: $3 \%$, W: $10 \%$ )

State: this category is highly variable as it contains not only fields that have been fertilised, but also species rich upland hay meadows and some diverse grasslands. Many of these sites are known, but others (for example, Chillingham Park, Northumberland) have remained outside general knowledge.

Potential changes: the drivers are similar to fertile grass, except that the more diverse sites would be threatened by even low applications of fertiliser or slurry, and moreover they often depend on traditional agriculture for their diversity, and would thus be influenced by a decline in management. In addition, a significant number of fields are under agri-environment agreements and are therefore particularly susceptible to support changes.

\section{Calcareous grassland (NA)}

State: together with the previous habitat, relatively few fragments of the original species rich assemblages remain, often in remote parts of the Yorkshire Dales and Assynt in the North West of Scotland. These patches are some of the most species rich habitats in Europe and have many distinctive species - if the sugar limestone grasslands are included, Gentiana verna would be present.

Potential changes: the rapid farming intensification that was the policy after the Second World War has now stabilised. The impact of intensification in this habitat is discussed by Petit \& Elbersen (2006). Indeed many of the patches that are left are now protected. However, there has been discussion that after Brexit such protection should be removed, which applies especially to those areas covered by agri-environment schemes.

Acid Grassland (E: $23 \%$, S: $16 \%$, W: $19 \%$ )

State: this habitat is the second most extensive in the uplands, and variable - from relatively species rich grassland to pure stands of dominant species such as Nardus. It extends from adjacent to the mountain wall, to many summit areas in Wales and The Scottish Borders. It is therefore difficult to generalise about its current state, except to say that currently almost all is grazed by sheep and to a lesser extent by deer.

Potential changes: the shift from cattle to sheep ended by the late 1950s, and now the most likely change is likely to be the removal of sheep grazing that could take place throughout the region were agricultural subsidies to stop following Brexit, an outcome which has been widely suggested. The impact will depend on the rate of loss, but also on local environmental conditions. Otherwise, hill land improvement is now scarce and the impact of acid rain has declined. Traditional shepherding is also on the decline and sheep management is now more extensive a trend, which could become more pronounced in future and will have localised effects on sward composition as indicated by Firbank et al. (2000).

Bracken (E: $4 \%$, S: $2 \%, \mathrm{~W}: 3 \%$ )

State: this habitat often forms dense plagio-climaxes with dense fronds. It is also expanding in areas where management is declining.

Potential changes: although sheep grazing may stop following Brexit, this is not likely to cause bracken expansion, but rather the decline in management by farmers of fields adjacent to the mountain wall were abandonment of entire landscapes to take place.

Dwarf Shrub Heath (E: $18 \%$, S: $14 \%$, W: $11 \%$ )

State: this habitat is under more varied pressures than any other, as shown by the block of high pressures in the impact table (Table 1), partly from natural factors such as nitrogen deposition, but mainly because of active management by man. At lower altitudes, it was 
Bunce R.G.H., Wood C.M., Smart S.M.: The Ecology of British Upland Landscapes. II. The influence of policy on the current character of the Uplands and the potential for change

originally forest, and therefore it is often overlooked that it is a degraded ecosystem in which, in some cases, the soils have since been modified by the high rainfall. Typically it is species poor, but locally can be quite rich in species. The structure is also variable depending on burning and grazing.

Potential changes: on account of the wide range of policies that directly affect this habitat, it is probably the one that could alter most widely following changes, such as those as a consequence of Brexit. On the one hand, acid grassland may shift to dwarf shrub heath with a decline in grazing (mainly by sheep) (Hill et al., 1992), but on the other the support from the CAP for grouse moor management would also stop, with the effects of fire discussed by Davies et al. (2016). In the absence of grouse management, as discussed above, this habitat could be colonised by trees as discussed above, and is therefore an important candidate for re-wilding.

Fen/marsh/swamp (E: $3 \%$, S: $3 \%, \mathrm{~W}: 2 \%$ )

State: although these habitats are low in area, they are important in all three countries for biodiversity, as they contain relatively rich assemblages and many distinct species often linked to faunal species

Potential changes: agricultural improvement through drainage has been the main cause of habitat loss (Firbank et al., 2000), so the possible policy abandonment of the uplands would have a major impact. However, many of the losses are not reversible so improvements may be small.

\section{$\operatorname{Bog}(\mathrm{E}: 9 \%, \mathrm{~S}: 33 \%, \mathrm{~W}: 4 \%)$}

State: most of the bogs in the Uplands are various types of blanket bogs, dependent therefore on high rainfall and poor drainage (the factors causing change are discussed in Firbank et al. (2000)). They have distinctive indicators such as Rubus chamaemorus. They are complex systems, and therefore have patches of species other than bog plants, such as Nardus and Deschampsia flexuosa. Active blanket bogs are important habitats in the European context, but many areas have been affected by peat cutting in the past and are no longer active although they can recover in time.

Potential changes: in the past, many bogs have been afforested but currently planting is not as widespread as formerly but, as stated in the coniferous forest section, this may change in the future. Not only are the planted areas affected, but also the bogs that remain in the catchments have reduced water levels, because of the ploughing. The damaging practice of deep ploughing is now not so common, but changes in policy in Scotland on afforestation could have a major effect. Bogs in the far north and islands are less likely to be planted because of lower yields. Nitrogen deposition is locally important in England and Wales but not so in the more remote north (Smart et al., 2005). Bog is of critical importance for the storage of carbon (see Ostle et al. (2009)) and the possibility that climate change will be reinforced by increased carbon dioxide emissions is expected to become increasingly important, with the associated increase in temperatures contributing to further release of greenhouse gases from the soil. Finally, there is some discussion that climate change and wind farms might cause drying out of bog surfaces.

\section{Montane (NA)}

State: this habitat is the result of slow development since the Ice Age and until recently. As the majority is isolated from policy changes, it has been relatively stable. However, it is sensitive because there is much bare ground which can be readily colonised by generalist species if the climate improves. 
Potential changes: as it occurs in very harsh environments, this habitat is not likely to be affected by policy. In contrast, the vegetation is highly sensitive to climate change and this is likely to cause expansion of generalist species and decline in arctic-alpines as has been shown in Europe in the Gloria project (Grabherr et al., 2010). Ronas Hill on Shetland could be most affected as it is at a low altitude (Wood \& Bunce, 2016).

\section{Inland Rock (NA)}

State: most of this habitat has few pressures, because it is mostly at high altitudes and is therefore relatively stable with the exceptions of Limestone Pavement and Caliminarian grassland. Moreover, the high proportion of bare rock would be slow to colonise.

Potential changes: the high altitude zone is likely to be similarly affected by climate change as montane. In contrast, limestone pavement would be influenced by lack of grazing leading to tree colonisation. But Caliminarian grassland is unlikely to change because of its high mineral content.

\section{Urban (NA)}

State: there are no large conurbations in the Uplands, only relatively small towns, villages and scattered housing. A recent trend is for the development of tourist facilities such as ski centres, chair lifts and water sports resorts. Although these occupy a small area they have important visual impacts and in the case of lifts, environmental pressures on high plateaus.

Potential changes: the extension of this habitat depends entirely on the policies of national and local planners but is usually adjacent to towns or villages except for isolated localised developments for example, by ski or water sport resorts. The pressure to create jobs from tourism could well increase this pressure but compared with the changes described above the environmental impacts are usually small.

\section{Standing open water (E: NA, S: $1 \%, \mathrm{~W}: 1 \%$ )}

State: most water bodies in England and Wales are reservoirs aside from the English Lake District, whereas in Scotland there are many lochs of different sizes. They therefore have varying levels, and are subject to rapid changes, as opposed to natural lakes which have more natural marginal floras and faunas. The northern dystrophic water bodies have important desmid and diatom populations.

Potential changes: in the south of the distribution, nitrogen deposition and eutrophication caused by transport and general pollution are problems linked to the overall policy of freedom of access to vehicles and especially diesel fuel, but the impact is not as acute as in the lowlands. The earlier policy of planting reservoir catchments has locally caused acidification and the afforestation policy sedimentation and nitrogen surges following felling.

\section{Rivers and streams (NA)}

State: in the Uplands, the rivers are relatively clean and have low pollution loads although the recent extreme storm events have had a major impact in sedimentation terms.

Potential changes: this habitat is not targeted by policies, except indirectly by those that affect the whole landscape (for example, afforestation and drainage whose impact is discussed above). 
Bunce R.G.H., Wood C.M., Smart S.M.: The Ecology of British Upland Landscapes. II. The influence of policy on the current character of the Uplands and the potential for change

Boundaries (Hedges E: $2 \%$, S: $12 \%$, W: $33 \%$; Walls E: $54 \%$, S: $43 \%$, W: $47 \%$ )

State: the state of walls varies locally, and often depends on agri-environment schemes for maintenance. Hedges are often overgrown and could be easily be removed as they are often species poor and therefore not protected by the Hedgerow Protection Scheme.

Potential changes. All boundaries except fences are thus under threat in a variety of scenarios, as they all require maintenance of different sorts. In addition, if all farms in a valley are combined to make an economic unit, then all traditional boundaries could be removed in an efficiency drive.

The Four categories below will all be affected by sea level rise but to different degrees. They are only present in the intermediate Uplands and Islands Zone and have many distinct species and rare coastal habitats such as machair.

\section{Supra littoral sediment (NA)}

State: consists of different types of sand dunes, many of which are very restricted in area, highly significant to biodiversity and susceptible to change. This zone should also include one of the Scottish habitats with unique species assemblages - machair.

Potential changes: all these habitats are likely to be severely affected by sea level rise as they are adjacent to the sea and could be destroyed by this process, as well as by increased storms. In addition, machair will also be affected if there is a decline in grazing.

\section{Supra littoral rock (NA)}

State: sea cliffs are more stable than the previous categories.

Potential changes: sea level rise, and the predicted increases in severity of storms with climate change, could increase the height of the spray zone and thus maritime plants. The rare arctic alpines on the cliffs could also be affected, as they are likely to be slow to adapt.

Littoral sediment (NA) and Littoral rock (NA) are not so likely to be as severely affected, as they are further out into the sea, and will therefore be submerged for longer, eventually becoming increasingly part of the marine environment.

\section{DISCUSSION}

The previous section demonstrates clearly the extent to which the majority of habitats are directly affected by policy, and therefore the outcome of the Brexit negotiations will be crucial in determining the direction and extent of change in the Uplands. The extent of these changes could be, to some degree, modified by the extent of designated areas and the degree of protection they afford.

One possibility is the decoupling on marginal systems in the Uplands, as discussed by Acs et al. (2010). They concluded using modelling procedures that the main effects of decoupling would be to reduce stocking rates and to change the mix of livestock activities. Agri-environment schemes could mediate the income losses from the process, but the removal of Single Farm Payments would lead to negative farm incomes. Currently, walls are generally in good repair because of support from National Parks and agri-environment schemes. Hedges on the other hand, are often overgrown and badly maintained.

House et al. (2010) give a comprehensive overview of the likely impact of climate change on decision making. They consider that climate change is already being experienced in British Uplands and is likely to exacerbate many of the drivers discussed in the present paper. 
Indeed, climate envelope models (for example Berry et al. (2002); Gallego-Sala et al. (2010)) suggest that over $50 \%$ of the British Uplands will be affected by climate change by the end of the $21^{\text {st }}$ Century and that they are likely to experience climates not typically associated with the region.

An examination of the map of the Uplands in the first paper (Bunce et al., 2018) would indicate that Dartmoor and Exmoor in South-West England are more likely to be affected by these changes than the Northern Scotland because they are within a matrix of milder climates.

This paper also pointed out that wildfires have not traditionally been associated with the scene in the Uplands but may become more common (already in 2018 there has been a major fire on Saddleworth moor, a boggy area in the Pennines which burned for over two weeks in the summer). In this context, burning on grouse moors could become more problematic if such dry summers continue.

The situation in the region could change rapidly if financial support of various kinds was removed from the Uplands, in which case many boundaries would decline in quality. They would even disappear if there is a move to creating large single farms.

\section{ACKNOWLEDGEMENTS}

Several people helped by discussing the issues presented, with Stephen Hall in particular making suggestions to improve the text. Thanks also go to an anonymous reviewer and Geoffrey Griffiths whose comments improved the manuscript.

\section{REFERENCES}

Ackrill, R. (2000). Common Agricultural Policy (Vol. 9). Sheffield: Sheffield Academic Press.

Acs, S., Hanley, N., Dallimer, M., Gaston, K. J., Robertson, P., Wilson, P., \& Armsworth, P. R. (2010). The effect of decoupling on marginal agricultural systems: implications for farm incomes, land use and upland ecology. Land Use Policy, 27(2), 550-563. doi: https://doi.org/10.1016/j.landusepol.2009.07.009.

Aldhous, J. R. (1997). British forestry: 70 years of achievement. Forestry, 70(4), 283-291. doi: https://doi.org/10.1093/forestry/70.4.283.

Angus, S. (2009). Dé tha cearr air a'mhachaire? Biodiversity issues for Scottish machair: an initial appraisal. Glasgow Naturalist, 25, 53-62.

Barr, C. J. (1996). Current status and prospects for key habitats in England. Part 3: Upland landscapes. Grange over Sands: Department of the Environment, Transport and the Regions, Insititute of Terrestrial Ecology.

Benayas, J. R., Martins, A., Nicolau, J. M., \& Schulz, J. J. (2007). Abandonment of agricultural land: an overview of drivers and consequences. CAB Reviews: Perspectives in Agriculture, Veterinary Science, Nutrition and Natural Resources 2, 1-14.

Berry, P., Dawson, T., Harrison, P., \& Pearson, R. (2002). Modelling potential impacts of climate change on the bioclimatic envelope of species in Britain and Ireland. Global ecology and biogeography, 11(6), 453-462. doi: https://doi.org/10.1111/j.1466-8238.2002.00304.x.

British Association for Shooting and Conservation (BASC), (2017). Grouse moor management. Rossett: British Association for Shooting and Conservation (BASC). 
Bunce R.G.H., Wood C.M., Smart S.M.: The Ecology of British Upland Landscapes. II. The influence of policy on the current character of the Uplands and the potential for change

Bunce, R. G. H., Barr, C. J., Gillespie, M. K., \& Howard, D. C. (1996). The ITE Land Classification: providing an environmental stratification of Great Britain. Environmental Monitoring and Assessment, 39, 39-46. doi: 10.1007/978-94-009-1653-1_5.

Bunce, R. G. H., Wood, C. M., \& Smart, S. M. (2018). The Ecology of British Upland landscapes. I. Composition of landscapes, habitats, vegetation and species. Journal of Landscape Ecology, 11(3), DOI: 10.2478/jlecol-2018-0015.

Bunce, R. G. H., Wood, C. M., Smart, S. M., Oakley, R., Browning, G., Daniels, M. J., Ashmole, P., Cresswell, J., \& Holl, K. (2014). The landscape ecological impact of afforestation on the British uplands and some initiatives to restore native woodland cover. Journal of Landscape Ecology, 7(2), 5-24. doi: https://doi.org/10.2478/jlecol-2014-0013.

Carey, P. D., Wallis, S., Chamberlain, P. M., Cooper, A., Emmett, B. A., Maskell, L. C., McCann, T., Murphy, J., Norton, L. R., Reynolds, B., Scott, W. A., Simpson, I. C., Smart, S. M., \& Ullyett, J. M. (2008). Countryside Survey: UK Results from 2007. Lancaster: NERC/Centre for Ecology \& Hydrology.

Davies, G. M., Kettridge, N., Stoof, C. R., Gray, A., Ascoli, D., Fernandes, P. M., Marrs, R., Allen, K. A., Doerr, S. H., \& Clay, G. D. (2016). The role of fire in UK peatland and moorland management: the need for informed, unbiased debate. Phil. Trans. R. Soc. B, 371(1696), 20150342. doi: https://doi.org/10.1098/rstb.2015.0342.

DEFRA. (2018). Health and harmony: The future for food, farming and the environment in a Green Brexit. Retrieved December 18, 2018, from https://www.gov.uk/government/ publications/the-future-for-food-farming-and-the-environment-policy-statement-2018/healt h-and-harmony-the-future-for-food-farming-and-the-environment-in-a-green-brexit-policystatement.

Evans, D., Morrison-Bell, C., McCracken, D., \& Thompson, D. (2017). The Uplands: Onwards and Upwards. BES Bulletin, 48(4), 46-47.

Fennell, R. (1997). The common agricultural policy: Continuity and change. Oxford.

Firbank, L. G., Smart, S. M., Van de Poll, H. M., Bunce, R. G. H., Hill, M. O., Howard, D. C., Watkins, J. W., \& Stark, G. J. (2000). Causes of change in British vegetation (ECOFACT volume 3): Merlewood: Institute of Terrestrial Ecology.

Forest Research. (2018). Timber Price Indices. Retrieved October 16, 2018, from https://www.forestresearch.gov.uk/tools-and-resources/statistics/statistics-by-topic/timber-s tatistics/timber-price-indices/.

Gallego-Sala, A. V., Clark, J. M., House, J. I., Orr, H. G., Prentice, I. C., Smith, P., Farewell, T., \& Chapman, S. J. (2010). Bioclimatic envelope model of climate change impacts on blanket peatland distribution in Great Britain. Climate Research, 45, 151-162. doi: https://doi.org/10.3354/cr00911.

Grabherr, G., Gottfried, M., \& Pauli, H. (2010). Climate change impacts in alpine environments. Geography Compass, 4(8), 1133-1153. doi: https://doi.org/10.1111/j.1749 -8198.2010.00356.x.

Grant, M., Mallard, J., Leigh, S., \& Thompson, P. S. (2012). The costs and benefits of grouse moor management to biodiversity and aspects of the wider environment: a review. Sandy, $U K: R S P B$.

Griffith, G. (2011). Deer Management in the UK. Wykey, Shropshire, UK: Quiller Publishing Ltd. 
Harrabin, R. (2017). Offshore wind power cheaper than new nuclear. Retrieved October 19, 2018, from https://www.bbc.co.uk/news/business-41220948.

Hill, M. O., Evans, D. F., \& Bell, S. A. (1992). Long-Term Effects of Excluding Sheep from Hill Pastures in North Wales. Journal of Ecology, 80(1), 1-13. doi: 10.2307/2261058.

House, J. I., Orr, H. G., Clark, J. M., Gallego-Sala, A. V., Freeman, C., Prentice, I. C., \& Smith, P. (2010). Climate change and the British Uplands: evidence for decision-making. Climate Research, 45, 3-12. doi: https://doi.org/10.3354/cr00982.

Jackson, D. (2000). Guidance on the Interpretation of the Biodiversity Broad Habitat Classification (Terrestrial and Freshwater Types): Definitions and the Relationship with Other Habitat Classifications (JNCC Report, No 307) (Vol. Report no. 307, pp. 73pp). Published online, http://jncc.defra.gov.uk/page-2433: JNCC.

Jacobsen, M., \& Delucchi, M. (2011). Providing all global energy with wind, water, and solar power, Part I: Technologies, energy resources, quantities and areas of infrastructure, and materials. Energy Policy, 39, 1154-1169. doi: https://doi.org/10.1016/j.enpol.2010.11.040.

Knudsen, A.-C. L. (2009). Farmers on welfare: the making of Europe's common agricultural policy: Cornell University Press.

Lund, H., \& Münster, E. (2006). Integrated energy systems and local energy markets. Energy Policy, 34(10), 1152-1160. doi: https://doi.org/10.1016/j.enpol.2004.10.004.

Malcolm, G., \& Maxwell, A. (2018). Grouse and Grouse Moors. London: A. and C. Black.

Monbiot, G. (2013). Feral: searching for enchantment on the frontiers of rewilding: Penguin UK.

Norton, L. R., Maskell, L. C., Smart, S. M., Dunbar, M. J., Emmett, B. A., Carey, P. D., Williams, P., Crowe, A., Chandler, K., Scott, W. A., \& Wood, C. M. (2012). Measuring stock and change in the GB countryside for policy: key findings and developments from the Countryside Survey 2007 field survey. Journal of Environmental Management, 113, 117-127. doi: 10.1016/j.jenvman.2012.07.030.

Ostle, N., Levy, P., Evans, C., \& Smith, P. (2009). UK land use and soil carbon sequestration. Land Use Policy, 26, S274-S283. doi: https://doi.org/10.1016/j.landusepol.2009.08.006.

Petit, S., \& Elbersen, B. (2006). Assessing the risk of impact of farming intensification on calcareous grasslands in Europe: a quantitative implementation of the MIRABEL framework. Ambio, 297-303. doi: https://www.jstor.org/stable/4315741.

Petit, S., Firbank, L., Wyatt, B., \& Howard, D. (2001). MIRABEL: models for integrated review and assessment of biodiversity in European landscapes. AMBIO: A Journal of the Human Environment, 30(2), 81-88. doi: https://doi.org/10.1579/0044-7447-30.2.81.

Pettorelli, N., Barlow, J., Stephens, P. A., Durant, S. M., Connor, B., Schulte to Bühne, H., Sandom, C. J., Wentworth, J., \& Toit, J. T. (2018). Making rewilding fit for policy. Journal of Applied Ecology, 55(3), 1114-1125. doi: 10.1111/1365-2664.13082.

Potter, L. (2014). Deer Stalking and Management. Marlborough The Crowood Press Ltd.

Quinn, B. (2018). Campaigners fight zip wire plan for Lake District beauty spot. The Guardian. Retrieved December 18, 2018, from https://www.theguardian.com/ uk-news/2018/jan/07/campaigners-zip-wire-lake-district-environmental-thirlmere-reservoir -attraction.

Reynolds, B., \& Edwards, A. (1995). Factors influencing dissolved nitrogen concentrations and loadings in upland streams of the UK. Agricultural water management, 27(3-4), 181-202. doi: https://doi.org/10.1016/0378-3774(95)01146-A. 
Bunce R.G.H., Wood C.M., Smart S.M.: The Ecology of British Upland Landscapes. II. The influence of policy on the current character of the Uplands and the potential for change

Robinson, M. (1986). Changes in catchment runoff following drainage and afforestation. Journal of Hydrology, 86(1-2), 71-84. doi: http://dx.doi.org/10.1016/00221694(86)90007-7.

Saidur, R., Rahim, N., Islam, M., \& Solangi, K. (2011). Environmental impact of wind energy. Renewable and sustainable energy reviews, 15(5), 2423-2430. doi: https://doi.org/10.1016/j.rser.2011.02.024.

Sandercock, B. K., \& Martin, K. (2011). Ecology, Conservation, and Management of Grouse: Published for the Cooper Ornithological Society: Univ of California Press.

Scottish Government (2016). Getting The Best From Our Land: A Land Use Strategy For Scotland 2016 - 2021. Retrieved October 17, 2018, from https://www.gov.scot/ Publications/2016/03/5773/4.

Scottish Natural Heritage (2016). Scoping a strategic vision for the uplands - Scottish Natural Heritage. Edinburgh: Scottish Natural Heritage.

Silcock, P., Brunyee, J., \& Pring, J. (2012). Changing livestock numbers in the UK Less Favoured Areas - an analysis of likely biodiversity implications. Sandy: Final Report prepared for the Royal Society for the Protection of Birds.

Smart, S., Ashmore, M., Hornung, M., Scott, W., Fowler, D., Dragosits, U., Howard, D., Sutton, M., \& Famulari, D. (2005). Detecting the signal of atmospheric N deposition in recent national-scale vegetation change across Britain. Water, Air and Soil Pollution: Focus, 4(6), 269-278. doi: 10.1007/s11267-005-3037-5.

Soule, M., \& Noss, R. (1998). Rewilding and biodiversity: complementary goals for continental conservation. Wild Earth, 8, 18-28.

Vickery, J., Tallowin, J., Feber, R., Asteraki, E., Atkinson, P., Fuller, R., \& Brown, V. (2001). The management of lowland neutral grasslands in Britain: effects of agricultural practices on birds and their food resources. Journal of Applied Ecology, 38(3), 647-664. doi: https://doi.org/10.1046/j.1365-2664.2001.00626.x.

Wood, C. M., \& Bunce, R. G. H. (2016). Survey of the terrestrial habitats and vegetation of Shetland, 1974 - a framework for long-term ecological monitoring. Earth Syst. Sci. Data, 8(1), 89-103. doi: 10.5194/essd-8-89-2016. 